\title{
CORRECTION
}

\section{Correction: Opportunities to implement a sustainable genomic medicine program: lessons learned from the IGNITE Network}

Kenneth D. Levy, PhD, Kathryn Blake, PharmD, Colette Fletcher-Hoppe, BA, James Franciosi, MD, MS, Daisuke Goto, PhD, James K. Hicks, PharmD, PhD, Ann M. Holmes, PhD, Sri Harsha Kanuri, MBBS, PhD, Ebony B. Madden, PhD, Michael D. Musty, BA, Lori Orlando, MD, Victoria M. Pratt, PhD, Michelle Ramos, MPH, Ryanne Wu, MD, MHS and Geoffrey S. Ginsburg, MD, PhD

Genetics in Medicine (2021) 23:2020; https://doi.org/10.1038/s41436-020-01054-0

Correction to: Genetics in Medicine 21:2019; https://doi.org/ 10.1038/s41436-018-0080-y; published online 12 July 2018

The original version of this Article contained an error in the spelling of the author Daisuke Goto, which was incorrectly given as Diasuke Goto. This has now been corrected in both the PDF and HTML versions of the Article.

\begin{abstract}
C) Open Access This article is licensed under a Creative Commons Attribution-NonCommercial-NoDerivatives 4.0 International License, which permits any non-commercial use, sharing, distribution and reproduction in any medium or format, as long as you give appropriate credit to the original author(s) and the source, and provide a link to the Creative Commons license. You do not have permission under this license to share adapted material derived from this article or parts of it. The images or other third party material in this article are included in the article's Creative Commons license, unless indicated otherwise in a credit line to the material. If material is not included in the article's Creative Commons license and your intended use is not permitted by statutory regulation or exceeds the permitted use, you will need to obtain permission directly from the copyright holder. To view a copy of this license, visit http://creativecommons.org/licenses/by-nc-nd/4.0/.
\end{abstract}

(c) The Author(s) 2020 